\title{
Research on Current Situation of British and American Literature Teaching
}

\author{
Guochang Zhang ${ }^{1, \text { a }}$
}

${ }^{1}$ Zhengzhou University of Industry Technology, Zhengzhou, Henan, China, 451100

aemail,

Keywords: Current Situation, British and American Literature, Teaching

\begin{abstract}
Literature Course is one of the main courses for English Majors in our country, which not only allows students to learn the rich literary knowledge and improve their level of appreciation of literature, while the students' quality education can also play a good role in promoting, but too much emphasis under practical principles, many English professional colleges has actually embarked on the "application of English professional" way. British and American Literature Courses status should have English as the main courses of embarrassment, literature courses in the cold, is an unavoidable fact.
\end{abstract}

\section{Introduction}

In our higher education students are learning English curriculum subjects, English and American Literature course is a main course. British and American literature courses are English language and literature students a basic course, also a four-year undergraduate English majors learning process throughout the course of the focus (for example, the first university, the second year of the Comprehensive English, English reading and other basic courses often you can see the selected works of English and American Literature text is selected as the text, even in the course of hearing the speech can be found information on English and American literature), it is the main subject after the end of undergraduate study stage graduate study phase of research one. The main purpose of teaching this course is to introduce the main British and American Literature to English majors, so that students have a certain literary quality, the main British and American literature have a certain understanding, based on the history and culture of the West to have a preliminary understanding.

As an English Language and Literature of the Founding of the Anglo-American literature courses are English majors to be the focus of a study course. And this course itself is also different from other professional courses features: It is an important basic course, but also requires a certain professional knowledge and professional skills improvement courses. It is a basic course, is due to what it needs and basic skills training comprises wide, such as the dramatic appreciation of poetry reading, the novel's comments are for listening, speaking, reading and writing ability of other items the focus of the training; it is to improve the curriculum, the performance in the teaching objectives of the course does not stop at the above basic skills training, which requires a good grasp of these basic skills on the basis of further improve the level of literary appreciation. On this basis, but also consider individual differences of students, such as student interest in literature, knowledge of the width. Therefore, for this important British and American literature courses course, we must pay full attention to the course of study the status and student learning, through the rational use of teaching materials and teaching classroom activities appropriate arrangements to ensure that reinforce students' basic skills on the basis of to improve students achieve literary quality.

\section{The Teaching Condition of British and American Literature}

Materials and Lessons. In English and American Literature Course Textbook process cannot avoid the question is the relationship between the history of literature and literary Readings text. Generally there are two approaches: First, the history of literature and literary Readings combining text, direct editing together, such as Liubing Shan written in English Literature 56 Henan People's Publishing House, Wu Weiren write, Foreign Language Teaching and Research Press 5 History of 
English Literature Publishing and Readings 6, are the various stages of English literature and British writers, works presentation combine to make the big time student writers and their works in which the background understanding; another History of Literature and Literary Readings sucked text separately, each written in a textbook.

Whether it is the kind of approach to the preparation materials, are faced with a common problem, namely lack of timetabling and teaching tasks are arduous problems. A set of English and American Literature course materials, selected writers tend to be three hundred years or even centuries forty-five famous writer in the history of literature, so there is not sufficient students to read literary works to understand the writer's real problems. Compare Chinese literature education, we find that the time gap between the two inputs: Chinese literature Chinese college students in contact with ancient times suffered 12 years of education in widely distributed before it enters the university; and with this control English majors to (4 years and not all the time in the contact) within four years of English and American literature for a considerable understanding of the arduous task visible. And most of the textbooks used in Readings in nature, is difficult to make students better writers and their works have a full understanding, which leads to the majority of students writers can do taste is just, even its understanding only stay on the surface some even left the impression that since the shallow and soon forgotten completely.

Teaching Methods. The traditional English and American literature courses are lecture-style teaching methods, classroom activities is teacher-centered, teacher lecture-based classroom teaching methods. This teaching method has its tradition in Anglo-American literature courses taught in this way is to take the vast majority of teaching. In such teaching methods, students mainly listen to teacher lectures, take notes, and actively participate in teaching activities which are not many. Teachers may arrange for students to read for the next lesson, but often cannot read the effective monitoring and timely counseling. Even in the increasing popularity of multimedia teaching methods today, lecture-based teaching methods is still the main way of teaching American Literature course, except that the teachers through a slide and video mode on the teachings on display, while teaching method itself is not substantially It changes.

Assessment Methods. Assessment methods English and American Literature course there are two: one is the paper type; one is the paper type. Both have advantages and disadvantages. Type examination papers generally refers for students have learned the basics of literature, writers, and other information on the work carried out tests to check students' mastery of what they have learned. The advantage of this approach is that the assessment can fully assess the situation in the past students remember what they have learned, emphasizing the students for the accumulation of basic knowledge of English and American literature, but the drawback is that students tend to assess the mechanical memory, but cannot fully assess students in the preliminary master of literary works on the basis of understanding and criticism of works, so that the goal of teaching English and American Literature courses reduced.

Paper type assessment generally refers to the requirements of the students have learned literary comment and reviews organized into papers. The advantage of this approach is to assess students in master writers and works on the basis of relevant information, the full expression of the understanding of the literary works according to their own ideas to make a comment. The disadvantage is that students are often due to a lack of knowledge and literary criticism Papers corresponding training of writing, and the paper written as "fanciful" book review; or meet the requirements to make the paper and the use of the Internet to download, copy journal articles and other plagiarism way.

Literature Teaching Problems With China's education reform in depth, the quality of education in the student's overall development process becomes more and more important, and the British and American literature and its subtle style of mold-like moisturizes things in silence nourish students overall improve the quality aspect plays an invaluable role. American Literature can not only improve students 'language training and literary quality, to develop their creative thinking and ability, but also can enhance students' awareness of cross-cultural communication and cultural appreciation for Humanistic Education provides an important platform. 
However, due to the effect of literature education cannot be immediate, a considerable number of university students under the influence of ideology and pragmatism employment pressure that reading English and American literature waste of time and not much use, this course of study passive. Although those language skills improved, but the empty language content, the lack of ideas, less personal opinion, the overall quality has declined. Further, as the English major pillar of English and American literature courses in and Linguistics and English for Specific Purposes courses have equal shares, while declining class, its development is faced with a growing challenge. Thus, the majority of English teachers exploring ways in the context of globalization, the times, pioneering and innovative, flexible use of various educational theories and concepts, the construction of English and American literature class focusing on becoming an enlightened thinking, the development potential of the quality of thinking education courses.

\section{The Ideas and Measures for Improvement the British and American Literature Teaching}

The majority of English and American Literature educators to give a correct understanding and attention it deserves, especially in English and American literature teaching teachers should improve their own quality at the same time, increase teaching and student emotional investment, take advantage of every opportunity outside the class help students to change these misconceptions course, ideologically so that they recognize the importance and necessity of English and American Literature course, stimulate their enthusiasm for learning.

Fully Understand the Importance of Learning English and American Literature. Learning to read English and American literature, especially English and American literature is the best way to improve English proficiency. As we all know, it is the art of literary language, the essence of language being mainly in literary texts. Therefore, the British and American Literature can give English learners colorful, vivid corpus, with its subtle meanings of words, ingenuity sentence, thought-provoking chapter to improve their language skills and comprehension skills. Learning English and American literature is a major way to understand Western culture. Authors and works of English and American literature and American culture will undoubtedly reflect the values, world view and way of thinking of the English nation, students in the learning process will gradually learn to feel the multicultural fun, develop their own cultural spirit of tolerance, and improve cross-cultural communication ability to succeed in an increasingly frequent and intense competition in the international cooperation.

Learning English and American literature is to develop critical thinking skills, an important way to improve personality. As Professor Wang Shou-ren said, the Anglo-American literature course "is a quality training class, students read English and American literature, active participation meaning of the text search, discovery, creative process, and gradually develop a keen ability to feel, to master the rigorous analytical methods, forming an accurate expression. This increased the wealth of emotional experience to feel abstract rational knowledge, analysis, skills, students will benefit from the infinite." This not only helps the search for critical thinking and application of knowledge, but also beneficial to the understanding for life. In this highly competitive era, inexperienced deep students will inevitably come under pressure from all sides, frustration, and even unfortunate. By reading classics, and great conversation, you can make them the meaning of life and philosophy of life more of a deep understanding and experience, in the face of any difficulties will not give up.

Adjust the Curriculum and Expand Teaching Object. In the past decade, the external environment and internal structure of higher education in China has undergone tremendous changes, undergraduate education was gradually transformed from education designed for liberal education. British and American Literature Teaching research if you only focus on English majors, cannot meet the language, literature and cultural quality of the comprehensive development needs of contemporary college students, while limiting the literature courses cultivate character, broaden their horizons and understanding of life, the rich spiritual and cultural life function implementation. In addition, as a general increase in the level of English of college freshmen, college English teaching focus should not only be limited to language teaching, but would like to improve the quality of students' English cultural shift, non-English Majors in English and American Literature 
elective and required course conditions maturing. Therefore, teaching English and American literature in the curriculum of English majors to break the limit, open to all students, to expand its teaching objects, making it a popular college students' humanistic curriculum. At this level, the teaching of English and American Literature goal should be positioned in the reading and interpretation of classical texts, the focus is to enable students to experience and insights; teaching content and form should be flexible and diverse, eclectic, mainly to provide students with a reading and thinking place, capacity to think independently. Anglo-American education and Correspondence College English literature education is to deepen the reform of college English teaching important content, but also to strengthen college students' quality education and training necessary to adapt policy in the 21st century talents social development.

Optimize the Teaching Content and Improve Teaching Methods. With the development and changes of the times and the development of literature, teachers should constantly optimize the teaching content to adapt Literature Course Literature Teaching in the 21st century, the new requirements, within a limited class of easy to difficult to follow the laws of cognition, to fit students' psychological and the ability to accept power as a starting point, carefully selected teaching material. On the selection should pay attention to the work of classical and modern combination of some of the early works Selected to moderate, mainly so that students are exposed to more modern and contemporary classics of English literature; works of beauty combined with the beauty of language and content note, both the selected reading material Literature reflects the linguistic features but also has a positive and progressive social significance and educational value. In addition, to teach students to read the works on the basis of the analysis, teachers need to use simple, accessible language describes some of the methods and theories of contemporary literary criticism, which open up their horizons, develop their critical thinking skills sharp and creative ability have very big help.

Teachers can use multimedia illustrations modern, high-quality courseware, we can save a lot of classroom time, effectively ease the contradiction between the limited hours and extensive content of English and American literature teaching objectives. In addition, teachers can rational use of modern teaching aids discs, slides, videos and multimedia teaching content enhanced to intuitive stimulate students' visual interest in learning, to arouse their and works ideological content emotional resonance conducive interactive Teaching and Learning, Literature course make truly enlightened thinking, the development potential of the humanistic curriculum. Furthermore, you can use oral presentations, poetry readings, drama fragment performances, panel discussions, student representatives and other forms of display, to enable students to participate in the classes, they eliminate the fear of psychological literature, literary thinking and make them feel exchange fun and effective to achieve the purpose of teaching literature courses.

\section{Conclusions}

In short, only in English and American literature to explore teaching objectives, curriculum, teaching content, teaching methods and other problems of quality education in the field of vision, and make practical improvements in order to better play in English and American Literature Course enrich students' language , literature and cultural knowledge, enhance the role of students' comprehensive quality aspects.

\section{References}

[1] Jia Xinzhang, Li Jingyuan. Foreign Language Study, Vol. 6 (2004) No 53, p.25-26

[2] Wang Yunhui, Wang Qunyong. Foreign Literature Studies, Vol. 12 (2005) No 27, p.74-76

[3] Qian Xiyuan, Jing Jianfen, Hou XuSiem. Xianning College, Vol. 30 (2004) No 19, p.144-145

[4] Wang Kuailiang. Nanchang Institute of Technology, Vol. 29 (2008) No 27, p.21-23

[5] Zhang Gongxu, Sun Jing. China Adult Education, Vol. 8 (2003) No 27, p.57-60 